\title{
Sexual Reproduction One Billion Years Ago
}

\author{
Petr N. Kolosov \\ Diamond and Precious Metal Geology Institute Siberian Branch, Russian Academy of Sciences, Yakutsk, Russia. \\ Email: p_kolosov@diamond.ysn.ru \\ Received December $7^{\text {th }}, 2012$; revised June $9^{\text {th }}, 2013$; accepted July $11^{\text {th }}, 2013$ \\ Copyright (C) 2013 Petr N. Kolosov. This is an open access article distributed under the Creative Commons Attribution License, \\ which permits unrestricted use, distribution, and reproduction in any medium, provided the original work is properly cited.
}

\begin{abstract}
The facts regarding to the early stages of algae evolution in the Precambrian are very rare (more than 542 million years ago). In this paper, the author describes the first discovered evidence that the sexual reproduction process took place one billion years ago. As it is known, sexual reproduction led to the diversity of living organisms on the Earth, and in general, accelerated the evolution process.
\end{abstract}

Keywords: Microorganisms; Cyanobacteria; Algae; Cells; Sexual Reproduction; Evolution; Neoproterozoic; Siberia

\section{Introduction}

A number of researchers have established, by the generalization of empirical data available for some continents, the morphological diversity of microorganisms about 1000 million years ago [1-8]. This was assumed to have been related to sexual reproduction in algae at the time. However, reliable facts regarding sexual reproduction during the Neoproterozoic (1000 - $542 \mathrm{Ma})$ have not been established. That is why the conclusions made by paleontologists concerning sexual reproduction taking place during the early stages of life history were regarded by many biologists as merely speculative [9].

\section{The Necessity to Find Evidence for Sexual Reproduction}

Thin sections of Proterozoic and, particularly, Neoproterozoic black cherts and macerated slides of black mudstones show that at that time the reproduction of Cyanobacteria and algae was asexual and occurred by cell division.

However, this is the simplest form of reproduction. It could not have produced the morphological diversity of the individuals observed in the Neoproterozoic in some continents. Therefore, it was necessary to find cogent evidence for sexual reproduction allowing for a transfer of genetic information (DNA) between contacting cells, since it was the transfer that ensured an increase of genetic variability in organisms [9].

With this in mind, the author studied over a thousand slides (made after the maceration of mudstones by oxi- dants) and thin sections of black cherts syngenetic with the host rocks. As a result, evidence for sexual reproduction in fossil algae was found in sample IV-36 collected from the Neoproterozoic Kumakhin formation of the Lakhanda group (Figure 1).

\section{Geology of the Area, Where Evidence for Sexual Reproduction Was Found}

The geological structure known as the Sette-Daban horstanticlinorium is located in northeast Asia, in the junction zone between the southeastern margin of the Siberian platform and the Verkhoyansk-Chukotka Mesozoides. The Meso- and Neoproterozoic (1600 - $545 \mathrm{Ma}$ ) sections of the region are among the most complete in the world, and have been carefully studied. The territory is referred to in geological literature as the Yudoma-Maya zone of the Uchur-Maya region. The Lakhanda and Uya groups of the region are assigned to the Neoproterozoic (1000 $545 \mathrm{Ma})$. The diversified microbiota of the Lakhanda group has been investigated by many micropaleontologists $(4,6,10)$. It provides an illuminating example of the morphological diversity of microorganisms existing from 1000 Ma onwards. The Kumakhin formation is the lowest subdivision of the Lakhanda group. The age of its basal layers is close to $1000 \mathrm{Ma}[11,12]$.

In Kumakhin times, a warm, shallow-water sea existed in the Uchur-Maya region, which provided favorable conditions for the thriving of microorganisms. For this reason, stromatolites were common there, especially during the second part of this time interval [11]. 


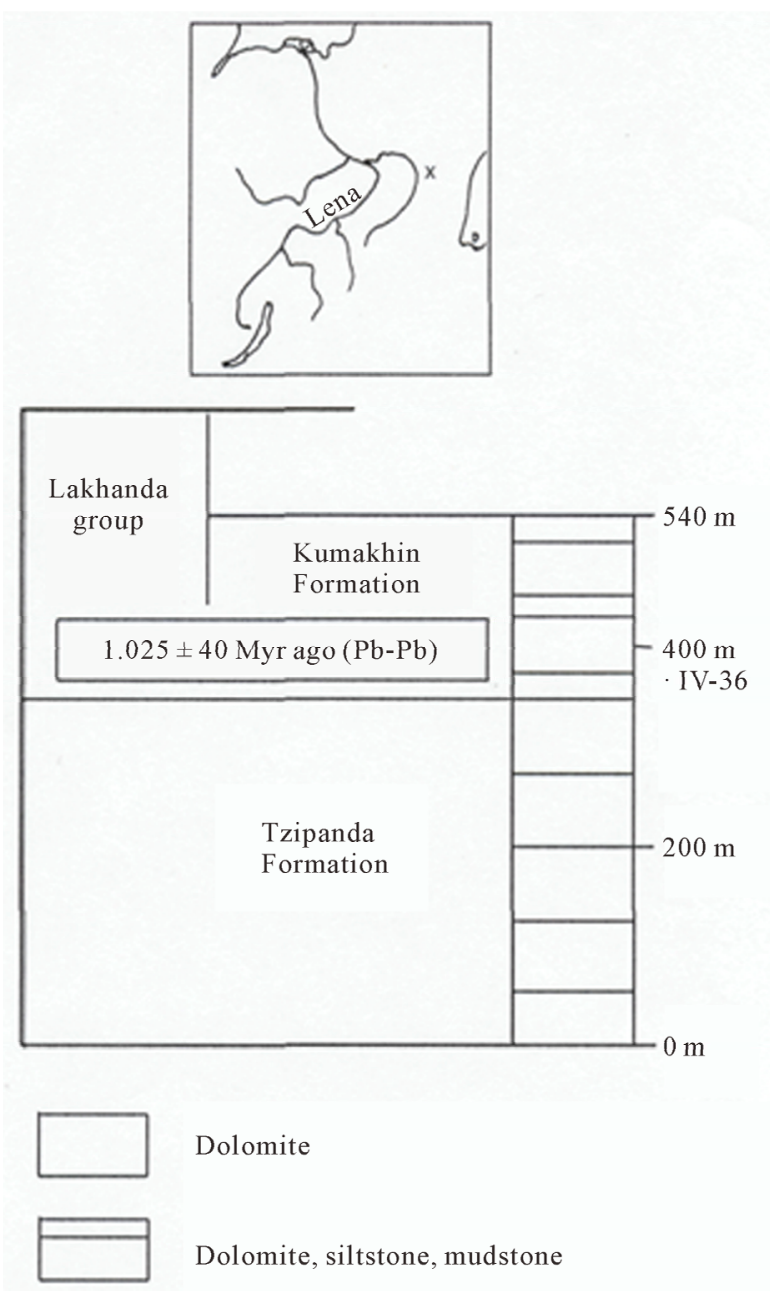

Figure 1. Location and stratigraphy of the Neoproterozoic Kumakhin formation, northeastern Asia.

The section from where sample IV-36 was collected is within the Sette-Daban area, in the Aldan river basin (Figure 1). It includes the Tzipanda (recrystallized and oncolitic dolomites, $350 \mathrm{~m}$ ) and Kumakhin (stromatolithic dolomites, mudstones, and siltstones, $190 \mathrm{~m}$ ) formations.

Within the same Uchur-Maya region, southeast of the sampling area (Figure 1), along the Maya river (right tributary of Aldan), the upper $20 \mathrm{~m}$ of the Kumakhin formation consist of mudstones. The microfossils extracted from them after maceration include organic walled coccoid and filamentous microorganisms, as well as relatively large spheroids $(200-500 \mu \mathrm{m})$ with spines on the surface (Trachyhistrichosphaera) [5,6]. This spheroid with spines is an additional evidence for age (about 1000 mln years ago) of the Kumakhin formation, where IV-36 sample was taken.

\section{Rock Material and Methods of Its Study}

The sample described was taken from a lens of black chert syngenetic with the enclosing dolomite, $21 \mathrm{~km}$ away from the base of the Kumakhin formation. 15 thin sections of the sample were prepared and studied using a NU-2 CARL ZEISS JENA $\times 1000$ microscope. A large number of silicified spheroidal fossilized microorganisms have been found, similar to the coccoid cyanobacteria and algae, i.e. lower organisms without nucleus, described earlier from the Neoproterozoic black cherts of Australia, Canada, China, Russia, and other countries $[1,4,5,10,13,14]$. They exhibit the closest resemblance to Gloeodiniopsis, Myxoccoides, and Glenobothrydion known from the Neoproterozoic Bitter Springs formation in central Australia [13,14]. They occur singly or in colonies. The spheroids range from 24 to $33 \mu \mathrm{m}$ in diameter and have a one- or two-layered membrane 0.4 to $3.6 \mu \mathrm{m}$ thick (Figure 2(a)). Reproduction is by binary fission (Figure 2(b)).

\section{Material Discussion}

The discovered incidence of cell fusion can be easily explained by recent algae studies $[9,15,16]$. This type of fusion differs from both the simple cell dividing process and from the fusion of two daughter cells after cell division, like in some Cyanobacteria (Chroococcus) [15]. The objects shown in Figure 2(b) are hypothetically fossilized cells.

They have no flagellum. However, we can see that one smaller cell (hypothetical male cell) with diameter 19.1 $\mu \mathrm{m}$ has moved to a larger non motile cell (hypothetical egg cell) with diameter $21.6 \mu \mathrm{m}$. The male cell is slightly pressed into the egg cell (Figure 2(b)).

Their fusion shows that they were in a vegetative state, and are reminiscent of gametes.

After the fusion of two vegetative cells, the content of the male cell transfused to the female cell, probably via conjugation channel. The results of these events are fertilization and further diploid zygote formation inside the maternal cell.

On Figure 2(b) we can see that the growing zygote almost reached the cell wall of the maternal cell.

The transfusion of content from one cell to another via conjugation channel and the internal growth of a zygote is typical for recent algae [16].

Thus, we have proof of a sexual process.

In Eubacteria, cells do not fuse during their sexual reproduction; in Cyanobacteria [15] a typical sexual reproduction process has not been revealed either. Hence, the organisms we found were single-celled fossilized algae, i.e. lower water plants with nucleus. Morphologically they look like simple unicellular organisms, however, the revealed sexual process tells us about their advanced physiology.

This, obviously, allowed them to adapt better to the often varying conditions of epicontinental basins of the 


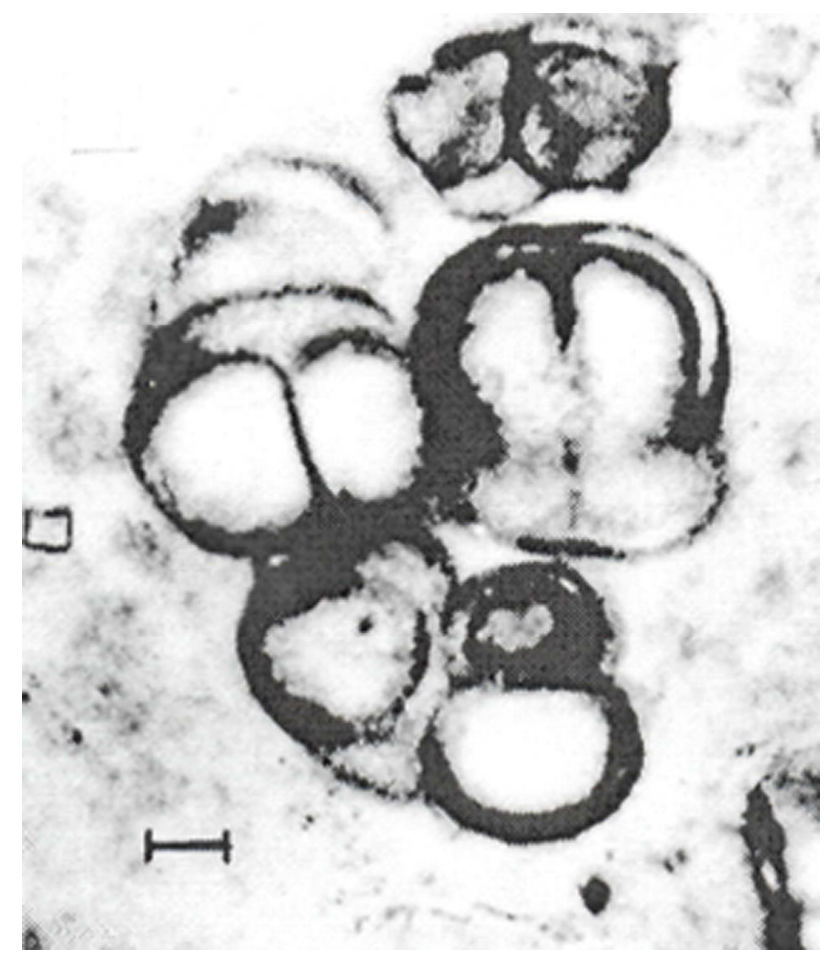

(a)

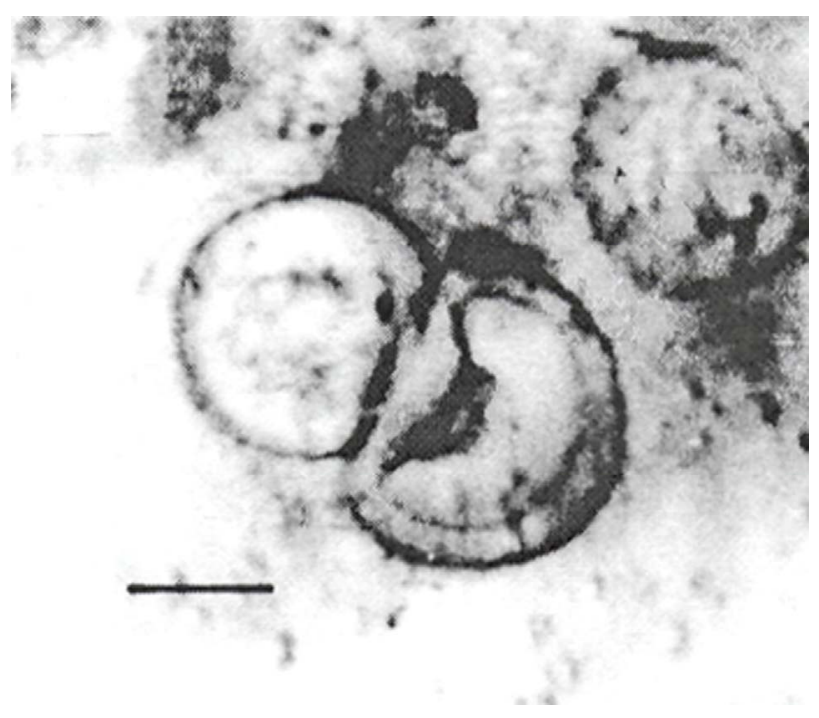

(b)

Figure 2. Microfossils from the Kumakhin formation. (a): Microorganism fertilization by cell dividing into two parts; (b): Maternal cell fertilization, resulting in diploid zygote formation. Scale equals $10 \mathrm{mkm}$.

Neoproterozoic. It results in the morphological diversity about 1000 million years ago, mentioned in introduction.

\section{Conclusions}

Whatever we call this type of sexual reproduction, hologamy, conjugation, or anisogamy, this great evolutionary advance that led to intergenerational change and to the appearance of organisms with dual heredity, happened no later than 1000 million years ago.

Now it is not just a supposition as it was before [9], but an obvious fact.

According to the evolution of modern organic world, it is well known that genetic information is transferred between contacting cells during sexual reproduction. DNA transfer ensures an increase of genetic variability in organisms. Therefore, organisms become evolutionarily advanced, their development and acquisition of different morphologies accelerate.

The increased number of individuals (number of stromatolitic layers) and the morphological diversity of algae in the Tonian (1000 - 850 millions years ago) and the Cryogenian (850 - 650 millions years ago) were the result of the sexual reproduction process and genetic recombination.

\section{REFERENCES}

[1] E. S. Barghoorn and J. W. Schopf, "Microorganisms from the Late Precambrian of Central Australia," Science, Vol. 150, No. 3694, 1965, pp. 337-339. doi:10.1126/science.150.3694.337

[2] P. N. Kolosov, "Morphology of Some Ancient Cyanophytes," The XII International Botanical Congress, Leningrad, 3-10 July 1975, p. 52.

[3] Z. Zhang, "Precambrian Microfossils from the Sinian of South China," Nature, Vol. 289, No. 5800, 1981, pp. 792793. doi: $10.1038 / 289792 \mathrm{a} 0$

[4] P. N. Kolosov, "Microorganisms Findings in Precambrian," Yakutsk, 1985, in Russian.

[5] T. V. Yankaouskas, "Precambrian Microfossils of the USSR,” Nauka, Leningrad, 1989, pp. 34-147.

[6] T. N. Hermann, "Organic World One Billion Years Ago," Nauka, Leningrad, 1990.

[7] A. H. Knoll, "The Early Evolution of Eukaryotes: A Geological Perspective," Science, Vol. 256, No. 5057, 1992, pp. 622-627. doi:10.1126/science. 1585174

[8] V. N. Sergeyev, A. H. Knoll, G. A. Zavarzin, "The First Three Billion Years of Life: From Procariots to Eucariots," Priroda, Vol. 6, 1996, pp. 54-67.

[9] N. P. O. Green, G. W. Stout and D. J. Taylor, "Biological Science," Cambridge University Press, Cambridge, 1984.

[10] V. G. Pyatiletov, "Microfossils of the Late Precambrian from the Uchur-Maya Region. The Late Precambrian and Early Paleozoic in Siberia. The Riphean and Vendian," IGG SD AS USSR, Novosibirsk, 1988, pp. 47-104.

[11] M. A. Semikhatov and S. N. Serebryakov, "The Siberian hypostratotype of the Riphean," Nauka, Moscow, 1983, in Russian.

[12] M. A. Semikhatov, G. V. Ovchinnikova, I. M. Gorokhov et. al., "Izotopic Age of the Middle and Upper Riphean Boundary: $\mathrm{Pb}-\mathrm{Pb}$ Geochronology of Carbonate Rocks of Lakhandian Series, Eastern Siberia," Reports RAN, Vol. 372, 2000, pp. 216-221. 
[13] J. W. Schopf and J. Paleontol, "Microflora of the Bitter Springs Formation, Late Precambrian, Central Australia," Journal of Paleontology, Vol. 42, No. 3, 1968, pp. 651688.

[14] J. W. Schopf, "Earth's Earliest Biosphere. Its Origin and Evolution," Princeton University Press, Princeton, 1983.
[15] R. G. South and A. Whittick, "Introduction to Phycology," Blackwell Scientific Publications, Oxford, London, 1987. (Basis of Algology, Translation from English, Mir, Moscow, 1990, pp. 9-197.)

[16] S. P. Vasser, N. V. Kondratieva, N. P. Masyk, et al., “Algae,” Reference Book, Naukova Dumka, Kiev, 1989. 